\title{
Adobe bricks with sugarcane molasses and gypsum to enhance compressive strength in the city Cogua, Colombia
}

\author{
Lady Sofia Rodriguez Cuervo (Main and Corresponding Author) \\ Department of Civil Engineering, Faculty of Engineering, Fundación Universitaria Agraria de Colombia \\ Cl. 170 \# 54a - 10, Bogotá D.C (Colombia) \\ lady.rodriguezc@gmail.com; rodriguez.lady@uniagraria.edu.co \\ https://orcid.org/0000-0003-0349-3077 \\ Manuscript Code: 13876 \\ Date of Acceptance/Reception: 16.11.2020/23.03.2020 \\ DOI: 10.7764/RDLC.19.3.358
}

\begin{abstract}
This paper presents a case study of the effect of adobe bricks stabilized with gypsum, sugarcane molasses and both combinations improving compressive strength. These bricks were produced by a hand-made process, which was empirical and had not been analysed before. All samples had the same unit weight and aspect ratio to obtain accurate data. An extensive series of test were conducted on adobe bricks stabilized with gypsum $(5 \%, 10 \%$ and $15 \%)$, sugarcane molasses $(5 \%, 10 \%$ and $15 \%)$, and gypsum in combination with sugarcane molasses $(5 \%, 10 \%$ and $15 \%)$ which were cured for one month. The results of the tests have shown that the grain size distribution was not optimum, which meant that samples stabilized with gypsum or sugarcane molasses did not exceed the resistance of the control sample. The former increased the strength, but the later decreased. Despite this, the sample stabilized with $2.5 \%$ gypsum and $2.5 \%$ sugarcane molasses had the best strength ( $2.15 \mathrm{MPa}$ ). This case study can contribute to better understanding the compressive strength of stabilized adobe bricks, which depends on the percentage of the clay and sand fraction, the moisture content of the soil, and the percentage of stabilizer. In summary, natural stabilizers could be an environmental solution to improve mechanical behaviour.
\end{abstract}

Key words: sugarcane molasses, adobe, gypsum, compressive strength, bricks.

Currently, the countryside has a necessity of improved materials for the construction of their houses which should be more resilient, more economical, safer, and adapted to the climate. These buildings are usually built with available resource materials and inherited techniques, which are part of the community's knowledge and the identity of these communities.

Almost $90 \%$ of the buildings in the world are categorized as vernacular architecture because they use clay techniques, which should be environmentally sustainable and meet the housing needs of developing countries like Colombia. It is possible through local materials and self-construction techniques (Mileto, López-Manzanares, García-Soriano, \& Cristini, 2017; Minke, 2005), but requires strategies to improve seismic response, mechanical behaviour and adaptation to the climate. Additionally, it is possible to reuse the adobe of structures that have been built around the world with these natural materials without generate waste (Degirmenci, 2008).

Colombia has vast rural areas with straw, mud, bamboo, wood, and other natural materials, some of which are used to produce adobe, rammed earth or bahareque walls (De La Peña, 1997). These have been widely used because they are cheaper and easier to obtain, but they need to improve their characteristics to guarantee the quality and safety of vernacular constructions (Bolaños, 2007).

In the case of adobe bricks, they are made from a artisanal mixture of clay, silt, sand, water and straw that communities can afford, but the strength is low with respect to other materials such as wood, concrete, and so on. The ideal mix should have at least $15 \%$ or $16 \%$ clay (Calatan, Hegyi, Dico, \& Mircea, 2016).

There are some building codes and standards which establish the minimum compressive strength of the adobe bricks in a wide range of 1.5 MPa to 6.89 MPa. For example, New Mexico code indicates 2.07 MPa, Zimbabwe code mentions 1.5 MPa (one story) and 2.0 MPa (two stories), ASTM E2392 shows 2.068 MPa, Australian standard indicates $1.15 \mathrm{MPa}$, and $\mathrm{ACl}$ mentions between 2.76 MPa to 6.89 MPa for sandy soil and 1.72 MPa to 4.14 MPa for clay soil (Calatan et al., 2016).

The development of adobes has increased in the last decades, however there are fewer studies that investigate their mechanical behavior. A study shows that adobes stabilized with Agave bagasse fibers increased compressive strength by $24 \%$ (Montes Bernabe, 2011). Another study modifies adobe blocks with sodium bentonite, these bricks were made using the CINVA RAM. Its result was to improve the compressive strength by $20 \%$ (Lozano \& Elizabeth, 2018). Another 
study takes blocks of earth with percentages of $5 \%, 10 \%$ and $15 \%$ rubber tuna, these bricks were made through the CINVA RAM, and the results shows the best compressive strength for the $15 \%$ rubber tuna sample (Bolaños Rodríguez, 2016). Some authors have found that steel shavings and sawdust increase the compressive strength of the adobe by $32 \%$.

In an experimental work, the effect of straw, cow dung, tuna's sap and bull blood on adobe compressive strength was developed. The results showed that the combination made with mud plus the addition of bull blood and cow dung obtained the highest strength (Chicaiza \& Mercedes, 2017). Moreover, some authors were carrying out asphalt emulsion tests with the mud mixture. The results have shown a better mechanical behaviour. (Arteaga Paucar \& Loja Saula, 2018).

On the other hand, the use of natural gypsum has led to an increase in strength values, which would represent an economic and environmental solution to improve the mechanical properties of adobe (Değirmenci, 2008), but their durability should be investigated (Medvey \& Dobszay, 2020). Regarding the use of molasses, a study investigated the effect of this material (treatment proportions of 5\%,10\%, 15\%, and 20\%) on the compressive strength of adobe blocks. The results demonstrated that molasses is an effective stabilizer obtaining better resistance, but it is not enough to overcome the use of Portland cement stabilizer (Vilane, 2010).

Colombia has many industries and associations that produce adobe bricks empirically. They rarely have standardization processes, material characterization, and high quality. Consequently, the bricks have an unsatisfactory safety behaviour.

Nowadays there are natural stabilizing materials that could improve compressive strength, such as sugarcane molasses, lime, fibers, rice husks or gypsum. They also reduce the carbon emissions that are causing the global climate change and the energy consumption in their manufacturing process.

In this context, this study aims to analyze the artisanal manufacture of adobe bricks with materials used by an artisanal manufacturing. The objective is to verify whether the compressive strength improves with natural stabilizers such as gypsum and sugarcane molasses.

\section{Materials and methods}

The materials used to produce adobe bricks were taken from an artisanal manufacturing in Cogua, which makes them empirically. This company is in the Andean region, which is the most populous region in the center of Colombia. The adobe was essentially a cohesive soil, and its grain size and chemical composition have not been changed.

Initially, the soil was dried to characterize its index properties. The experimental results were:

- The grain size distribution was $58 \%$ clay, $6 \%$ silt, and $48 \%$ sand without organic material (Figure 1 ).

- The specific gravity of solids was 2.70 .

- The liquid limit was $46 \%$, the plastic limit was $20.6 \%$, and the plasticity index was $25.4 \%$.

- The maximum dry density of adobe brick without stabilizers was $1.72 \mathrm{~g} / \mathrm{cm}^{3}$, and the optimum moisture content was $17.1 \%$ (Figure 2).

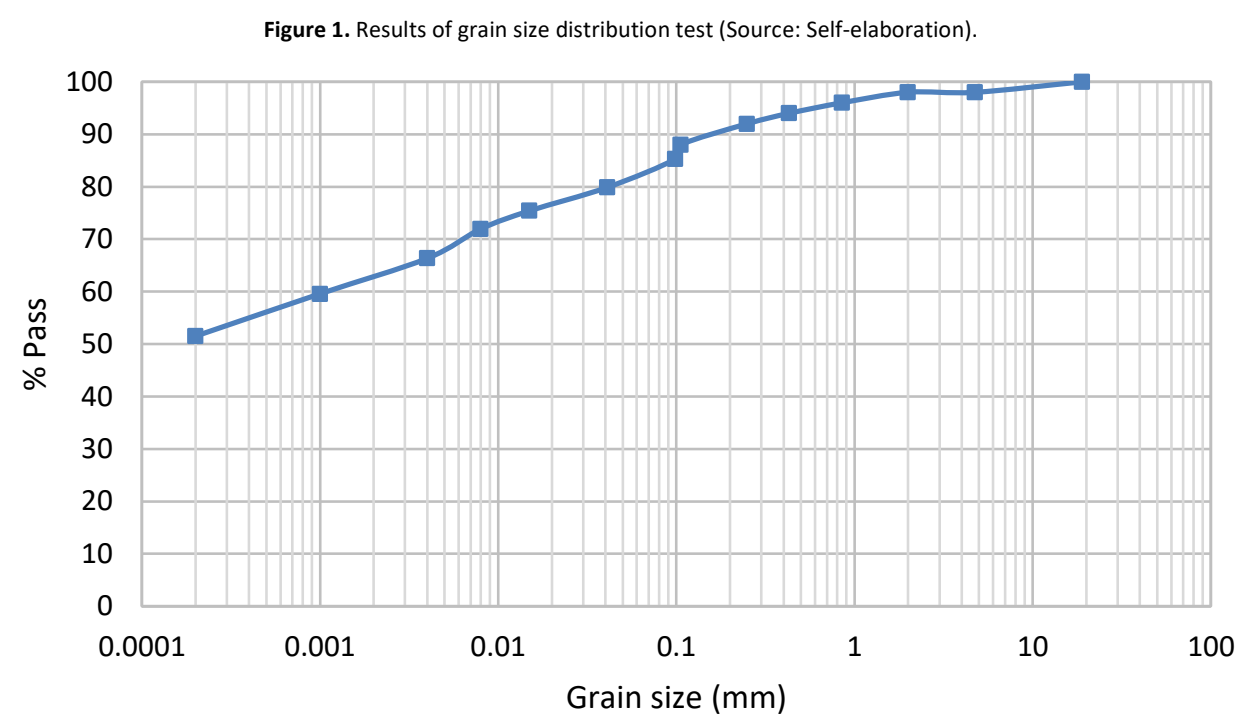




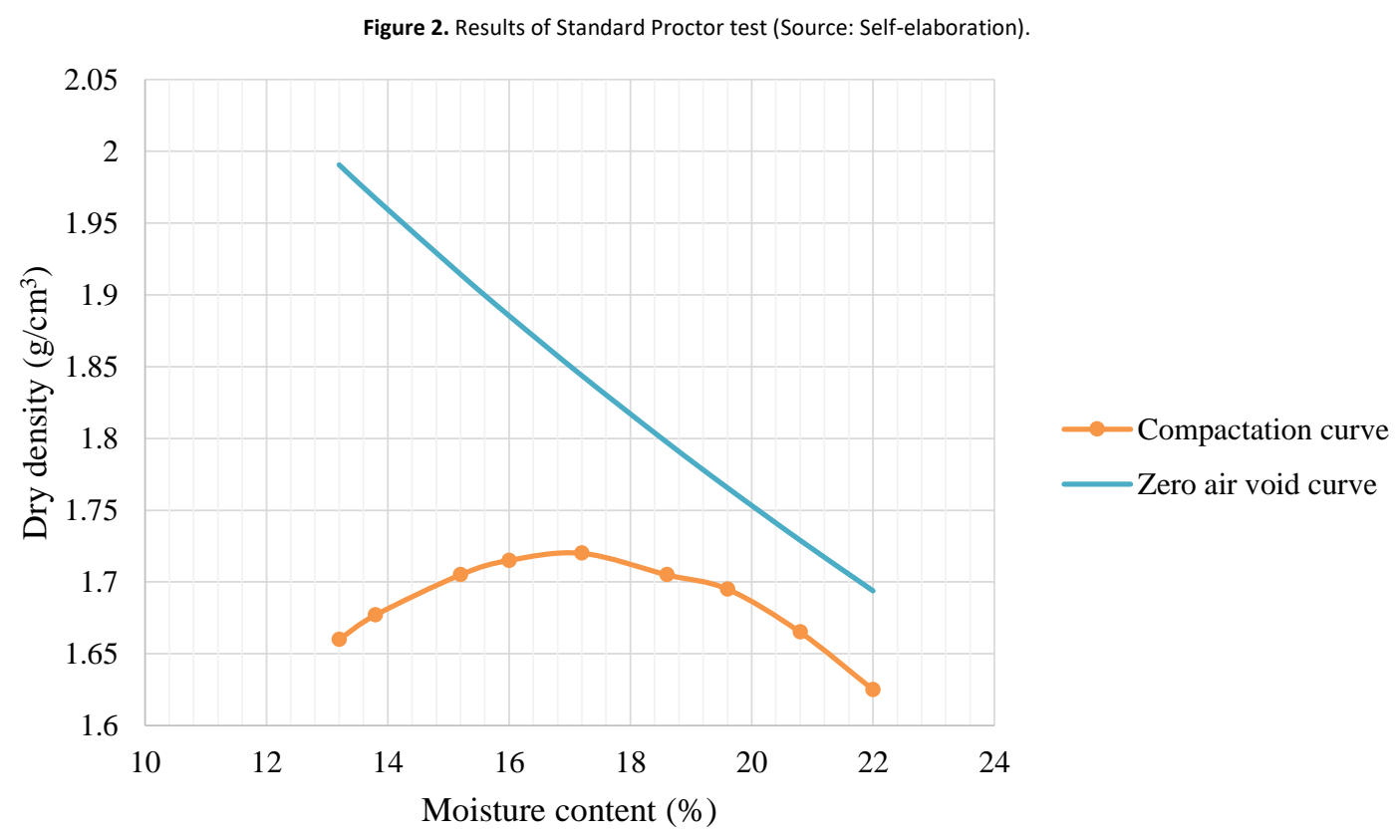

The bricks were prisms of $10 \times 20 \times 10 \mathrm{~cm}^{3}$. The first step in making the bricks was to dry the soil under normal storage conditions between $15^{\circ} \mathrm{C}$ to $20^{\circ} \mathrm{C}$ in a dry, clean room for one week. The material was disaggregated. Afterwards, the water was added until it reached $17.1 \%$ moisture content and mixed with the dry soil. This amount of water was selected according to the Proctor test. Then, the stabilizers were mixed to obtain a homogeneous material.

The tests were carried out with three different combinations of stabilizers: only with gypsum (Değirmenci, 2008), only with sugarcane molasses (Rodríguez \& Saroza, 2006; Stulz \& Mukerji, 1997; Vilane, 2010), and gypsum and sugarcane molasses. For each combination, different proportions of these stabilizers were used in relation to the dry mass of the control sample. Gypsum stabilized adobe bricks had 5.0\%, 10\% and 15\% gypsum in relation to the dry mass of the control sample. Sugarcane molasses stabilized adobe bricks had 5.0\%, 10\% and $15 \%$ sugarcane molasses in relation to the dry mass of the control sample. Gypsum and sugarcane molasses stabilized adobe bricks had $2.5 \%$ sugarcane molasses and $2.5 \%$ gypsum, $5.0 \%$ sugarcane molasses and $5.0 \%$ gypsum, and $7.5 \%$ sugarcane molasses and $7.5 \%$ gypsum in relation to the dry mass of the control sample.

After that, the mixtures were poured in a wooden mould to have the standard dimensions, which were $10 \times 20 \times 10 \mathrm{~cm}^{3}$. All treatments had three samples so that the results meet the criteria of reliability and validity. The samples were cured for 28 days. At that time, a hydraulic testing machine with a total capacity of $1000 \mathrm{kN}$ was used for testing specimens in compression. The compression of the samples was tested based on NTC 4017 standard, which is a Colombian Technical Standard that includes methods for sampling and testing masonry units and other clay products, applying correction factor by aspect ratio using Equations 1-2.

$$
\begin{gathered}
f_{c}^{\prime}=\frac{q_{\max }}{A_{e}} k \\
k=\frac{-0.374}{h / b}+1.611
\end{gathered}
$$

Where $f_{c}^{\prime}$ is the compressive strength, $q_{\max }$ is maximum load, $A_{e}$ is specimen area, $k$ is correction factor by aspect ratio, $h$ is height, and $b$ is width.

\section{Results and discussion}

The grain size distribution was $58 \%$ clay, $6 \%$ silt and $48 \%$ sand. The New Mexico State University suggests "a mixture of not more than $1 / 3$ clay, not less than $1 / 2$ sand and never more than $1 / 3$ silt" (Virkkala, Johnson, Shelter, \& Rudanko + Kankkunen Architects, n.d.). Therefore, the clay fraction had an amount greater than the optimum value, and the sand was much closer to the ideal value. Consequently, the Cogua company needs to optimize the grain size distribution for the future production of adobe bricks, but this study kept the original material to validate the compressive strength values. 
Thirty adobe bricks with gypsum, sugarcane molasses or both were tested at $1 \mathrm{~mm} / \mathrm{min}$ until failure. They had an average aspect ratio of $0.98(p=.05)$ and an average total unit weight of $18.5 \mathrm{KN} / \mathrm{m}^{3}(p=.05)$. The control sample (without stabilizer) have shown a compressive strength of $1.97 \mathrm{MPa}$ and the moisture content was 5.9\% (Figure 3), which was relatively low compressive strength due to the high clay content (58\%) and the lack of coarse sand. Its swelling was medium according to the liquid limit (46\%) (Yilmaz, 2004). Therefore, the material used by the Cogua company should not be used to produce adobe. The failure of the samples were vertical cracks in the lateral faces followed by fragmentation in the frontal faces (Figure 4).
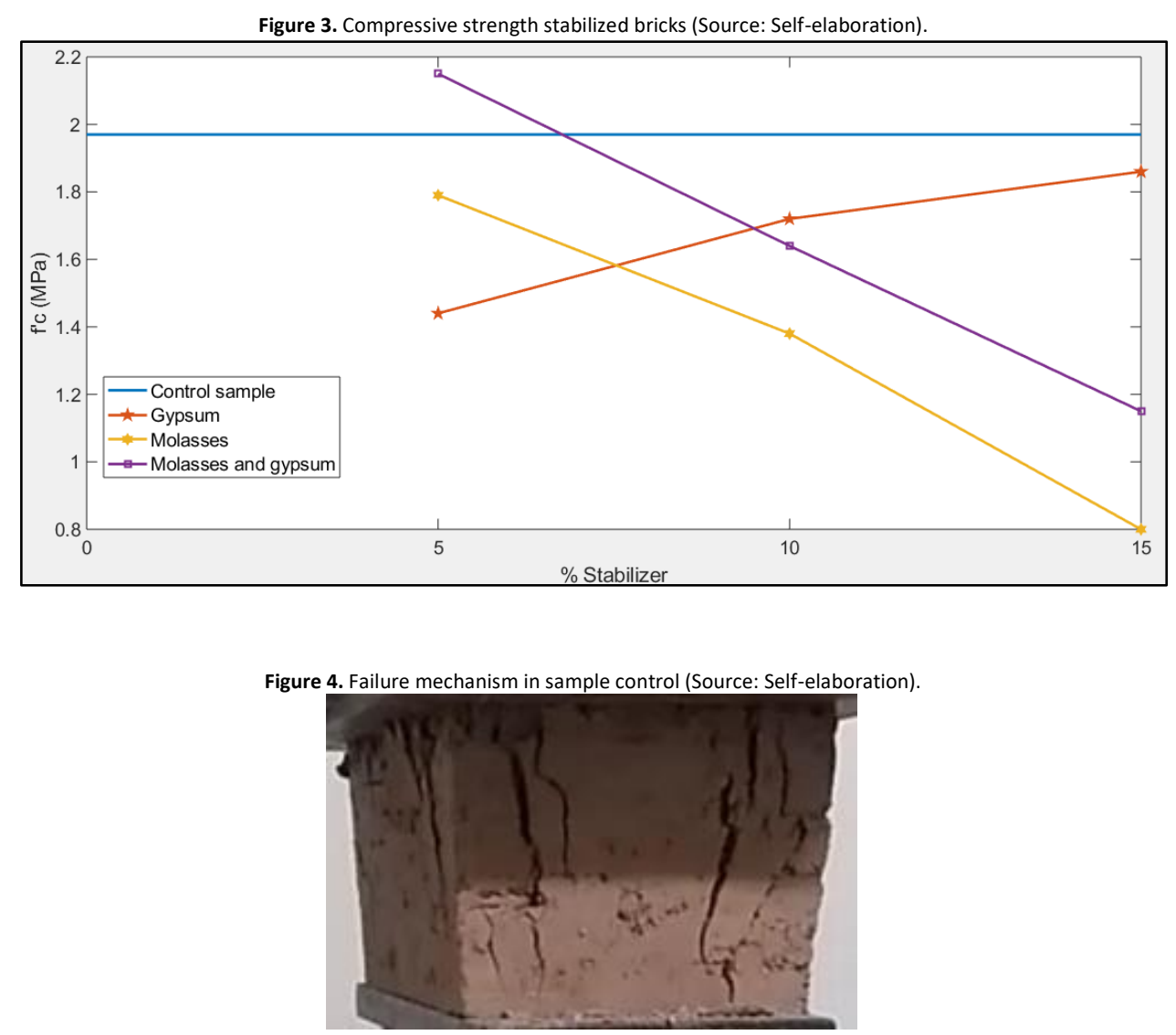

The effect of natural stabilizers has been determined. The compressive strength will start to increase if the gypsum percentage increases with a positive correlation coefficient of $90 \%(p=.121)$, but it does not exceed the strength value of the control sample (Figure 3). Other studies have found an increase in compressive strength, but the maximum value was 4.72 MPa for 25\% gypsum addition (Degirmenci, 2008), which is higher than $1.86 \mathrm{MPa}$ (maximum value in this study). Another study has found the same behaviour (Türkmen, Ekinci, Kantarcl, \& SarıcI, 2017), but the values were 4.58 $\mathrm{MPa}$, which is higher than this research. Other studies have found an increase in strength just above $3 \mathrm{MPa}$ (Pekmezcí, Kafescíoglu, \& Agahzadeh, 2012).

This tendency happened because the samples have shown more clay fraction than sand fraction compared to the amount used in other studies, and the stabilizer was at $15 \%$, while other studies used it at $25 \%$. For these reasons it is important to limit the percentage of clay and increase the fractions of silt and sand.

The average moisture contents were $2.67 \%$ (5\% gypsum), $4.87 \%$ (10\% gypsum) and $7.14 \%$ (15\% gypsum). This shows a tendency to increase the moisture content with the increase in gypsum, but it contradicts the results of other studies (Ashour, Korjenic, \& Korjenic, 2015). In addition, the added water was greater to develop the cementing properties of the gypsum. Gypsum could absorb water from environmental conditions that led to a reduction in compressive strength (Prakaypan, 2002). Furthermore, some authors report that the moisture equilibrium of the brick is influenced by the pore size, which means that the brick structure had a more specific surface area and percentage of micropores led by clay particles (variable surface charge), and modified the structure / water interactions that performed a low compressive strength(Ashour et al., 2015).

Regarding cracks, the samples have shown vertical cracks in the lateral faces with fragmentation not predominant in the frontal faces. If the gypsum increases, the cracks are more vertical and deeper (Figure 5). 


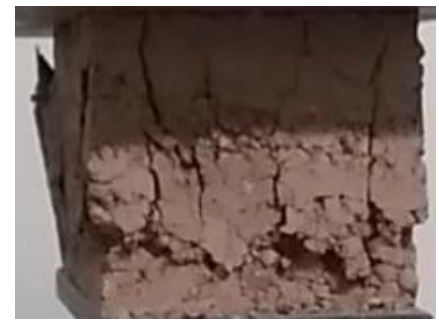

a- $5 \%$ gypsum

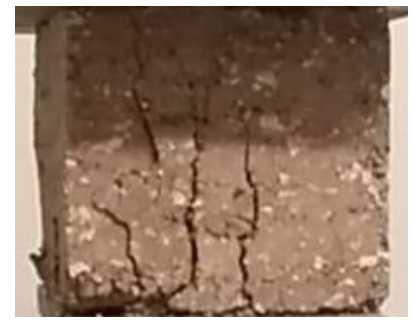

b- $10 \%$ gypsum

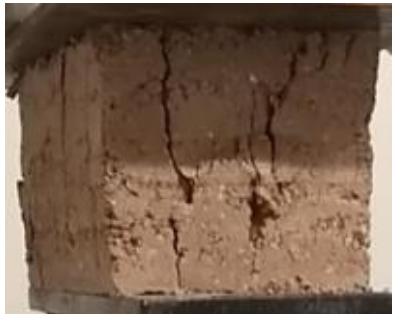

c- $15 \%$ gypsum

Regarding the sugarcane molasses stabilizer, if its percentage increases in the adobe, the compressive strength will begin to decrease with a negative correlation coefficient of $98 \%$ ( $p=.127$ ) (Figure 3). The average moisture contents were $9.40 \%$ ( $5 \%$ sugarcane molasses), $12.2 \%$ (sugarcane molasses) and $15.2 \%$ (sugarcane molasses) which contributed to reduce the strength. This trend was opposed to the results of another study that found acceptable values (between 3.5 MPa and 4.4 MPa) for compressive strength with 15\% sugarcane molasses (Vilane, 2010). The basic reason is that the clay fraction was larger and interacted with the sugarcane molasses as a retardant.

In relation to cracks, the samples have presented short vertical crack on the lateral faces followed by a deeper vertical crack on the frontal faces. If the sugarcane molasses content increases, the samples reduce the appearance of cracks (Figure 6).

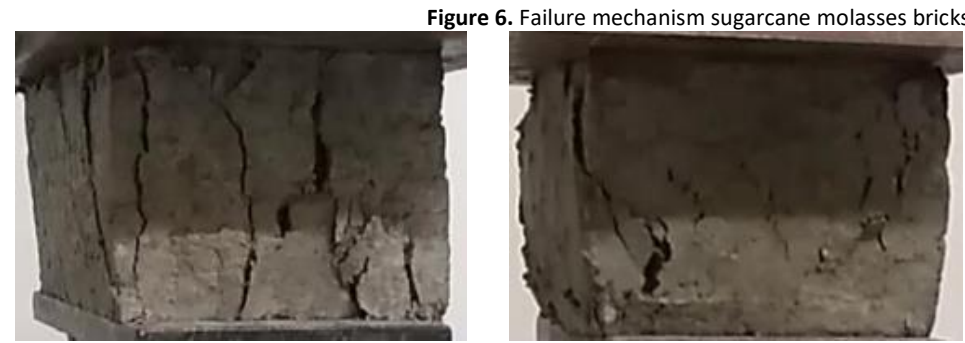

a- $5 \%$ sugarcane molasses

b- $10 \%$ sugarcane molasses

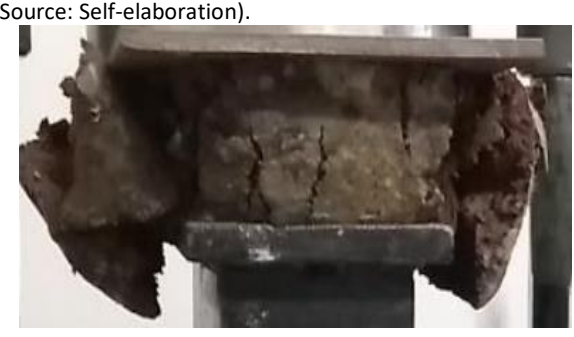

c- $15 \%$ sugarcane molasses

Relating to gypsum and sugarcane molasses stabilizers, if their percentages increase, the compressive strength will begin to decrease with a negative correlation coefficient of $99.9 \%$ ( $p=.0074)$ (Figure 3$)$. The average moisture contents were $6.08 \%$ (2.5\% gypsum and $2.5 \%$ sugarcane molasses), $10.8 \%$ (5\% gypsum and $5 \%$ sugarcane molasses) and $11.2 \%(7.5 \%$ gypsum and $7.5 \%$ sugarcane molasses), which are larger and contribute to reducing strength.

The critical point (2.15 $\mathrm{MPa}$ ) at $2.5 \%$ sugarcane molasses and $2.5 \%$ gypsum improved the compressive strength by $9.14 \%$, the other proportions ( $5 \%$ sugarcane molasses and $5 \%$ gypsum, $7.5 \%$ sugarcane molasses and $7.5 \%$ gypsum) decreased the resistance. This behaviour was due to the lowest moisture content, and gypsum with sugarcane molasses interacted to create strong forces to support the applied axial load. Nevertheless, this strength value (2.15 MPa) was able to overcome the minimum compressive strength established by some international codes between $1.5 \mathrm{MPa}$ to 2.0 MPa (Calatan et al., 2016). As far as this author's knowledge goes, there were no studies to investigate the influence of the combination of sugarcane molasses and gypsum on adobe bricks. Figure 7 illustrates the failure mechanism, which was cone at the top sample followed by cracks on the lateral faces and material fragmentation.

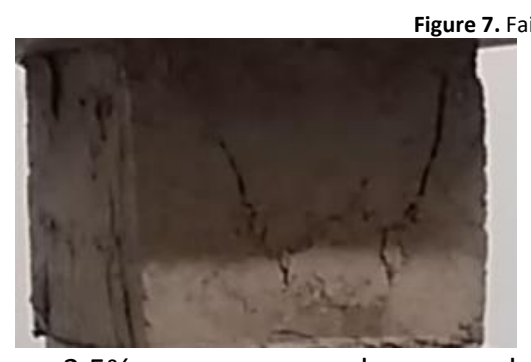

a- $2.5 \%$ sugarcane molasses and $2.5 \%$ gypsum

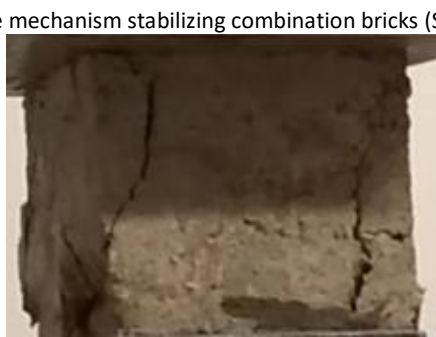

b- $5 \%$ sugarcane molasses and $5 \%$ gypsum

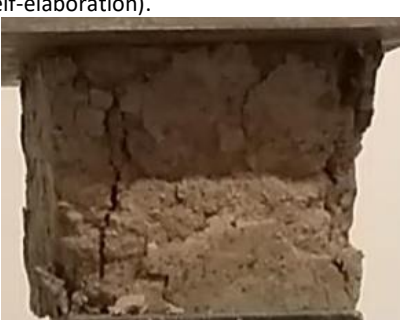

c- $7.5 \%$ sugarcane molasses and 7.5\% gypsum 
One-way ANOVA analysed the association between the same percentage of stabilizer and the compressive strength. The samples with $5 \%$ stabilizer have shown statistically significant differences in the average compressive strength, depended on the natural stabilizer, $F(2,6)=7.00, p=.027$. These results showed that adobe bricks stabilized with sugarcane molasses showed the lowest average strength, and adobe bricks stabilized with gypsum had the highest average strength (Figure 8). All average strength exceeded the minimum compressive strength on some international codes between 1.5 MPa to 2.0 MPa (Calatan et al., 2016).

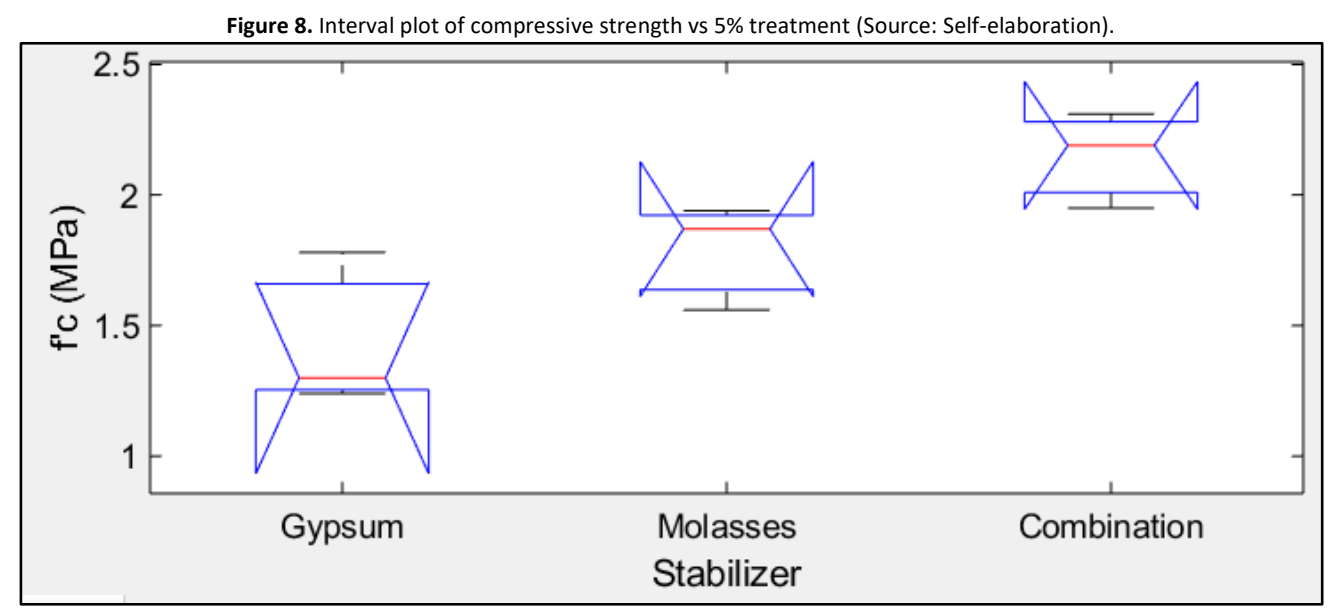

Samples with a $10 \%$ stabilizer had statistically significant differences in strength to average compression depending on the natural stabilizer, $F(2,6)=7.64, p=.022$. These results have shown that adobe bricks stabilized with gypsum had the lowest average strength, and that adobe bricks stabilized with gypsum and sugarcane molasses had the highest average strength (Figure 9). The samples with gypsum and combination of stabilizers (gypsum and sugarcane molasses) exceeded the minimum compressive strength of some international codes between $1.5 \mathrm{MPa}$ to $2.0 \mathrm{MPa}$ (Calatan et al., 2016).

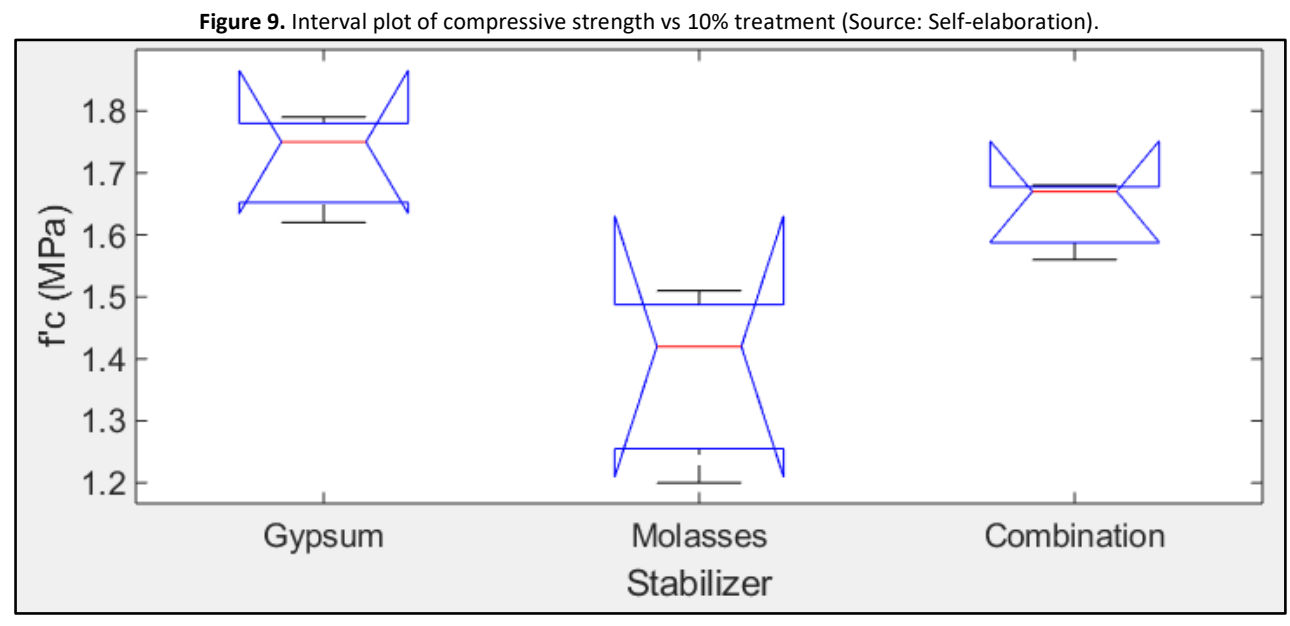

The samples with $15 \%$ of stabilizer have not shown statistically significant differences in the average compressive strength between gypsum, sugarcane molasses and their combination, $F(2,5)=5.38, p=.057$. These results have shown that the adobe bricks stabilized with sugarcane molasses had the lowest average resistance, and the adobe bricks stabilized with gypsum have shown the highest average resistance (Figure 10). These results were in accordance with the behaviour of the samples with $5 \%$ stabilizer. It is important to note that samples with gypsum exceeded the minimum compressive strength of some international codes between 1.5 MPa to 2.0 MPa (Calatan et al., 2016). 
Figure 10. Interval plot of compressive strength vs $15 \%$ treatment (Source: Self-elaboration).

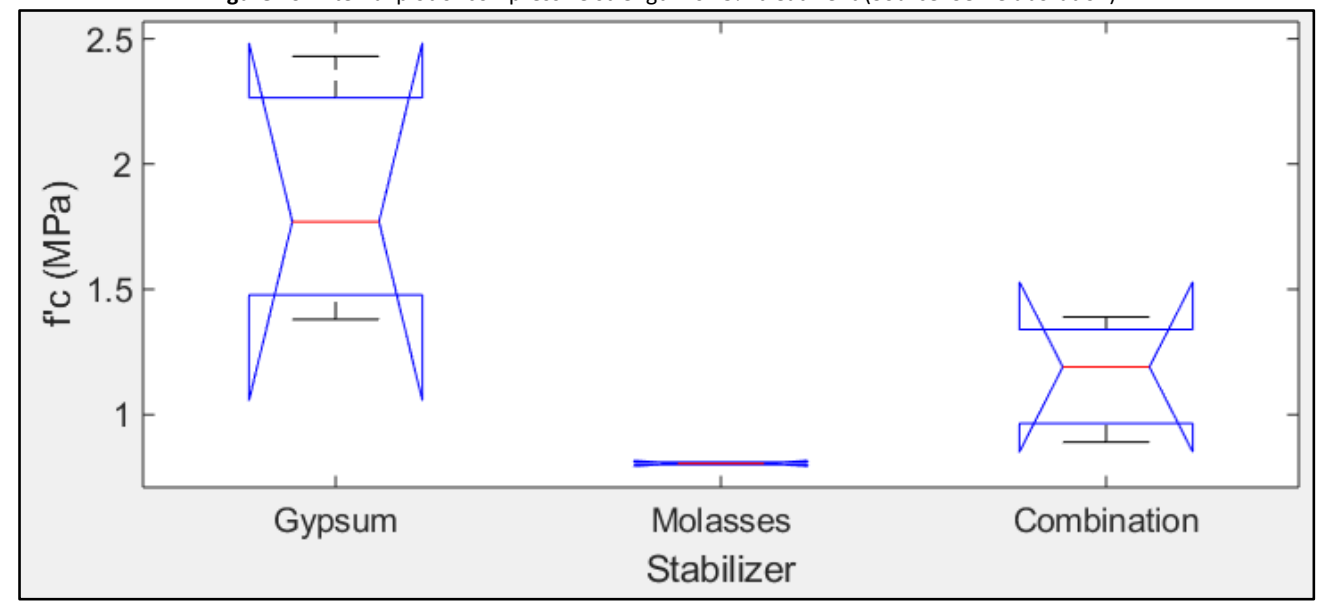

The effect of adobe bricks stabilized with gypsum, sugarcane molasses and both combinations was investigated in this study. The following conclusions summarize the study:

- The adobe construction materials used in this study were classified as sandy clay, which was not ideal to produce bricks. This which means that the artisanal manufacturing should change the material they use to produce the bricks. Additionally, water added to the mixture was higher, hence the structure / water interactions led the low compressive strength in almost all samples.

- Adobe bricks with gypsum have shown better compressive strength (1.86 MPa), although not sufficient toto overcome the compressive strength of the control sample (1.97 MPa).

- Adobe bricks with sugarcane molasses have revealed the worst compressive strength ( $0.80 \mathrm{MPa}$ for $15 \%$ stabilizer).

- Adobe bricks with $2.5 \%$ gypsum and $2.5 \%$ sugarcane molasses were the main stabilizers, which enhanced the compressive strength to $2.15 \mathrm{MPa}$ that represented an increase of $9.14 \%$.

- Stabilization with gypsum and sugarcane molasses has been a solution to enhance the compressive strength of the adobe bricks produced by the Cogua company, but the grain size distribution should be optimized.

- All adobe bricks have shown cracks in their faces, and some of them had fragmentation throughout the tests.

- It is important to continue doing research with sugarcane molasses and gypsum using an optimal grain size distribution of the soil.

Arteaga Paucar, J. M., \& Loja Saula, L. A. (2018). Diseño de adobes estabilizados con emulsión asfáltica (Universidad de Cuenca). Universidad de Cuenca, Cuenca. Retrieved from http://dspace.ucuenca.edu.ec/handle/123456789/30332

Ashour, T., Korjenic, A., \& Korjenic, S. (2015). Equilibrium moisture content of earth bricks biocomposites stabilized with cement and gypsum. Cement and Concrete Composites, 59, 18-25. https://doi.org/10.1016/j.cemconcomp.2015.03.005

Bolaños Rodríguez, J. (2016). Resistencia a compresión, flexión y absorción del adobe compactado con adición de goma de tuna. Universidad Privada del Norte. Retrieved from https://repositorio.upn.edu.pe/handle/11537/10482

Bolaños, S. R. (2007). El uso masivo de la tierra como material de construcción en Colombia. 20, 11.

Calatan, G., Hegyi, A., Dico, C., \& Mircea, C. (2016). Determining the Optimum Addition of Vegetable Materials in Adobe Bricks. Procedia Technology, 22, 259-265. https://doi.org/10.1016/j.protcy.2016.01.077

Chicaiza, L., \& Mercedes, S. (2017). Estudio de la resistencia a compresión del adobe artesanal estabilizado con paja, estiércol, savia de penca de tuna, sangre de toro $y$ análisis de su comportamiento sísmico usando un modelo a escala. Retrieved from https://repositorio.uta.edu.ec:8443/jspui/handle/123456789/26585

De La Peña, D. (1997). Adobe, características y sus principales usos en la construcción. Instituto Tecnológico de la Construcción, México.

Degirmenci, N. (2008). The using of waste phosphogypsum and natural gypsum in adobe stabilization. Construction and Building Materials, 22(6), 1220-1224. https://doi.org/10.1016/j.conbuildmat.2007.01.027 
Değirmenci, N. (2008). The using of waste phosphogypsum and natural gypsum in adobe stabilization. Construction and Building Materials - CONSTR BUILD MATER, 22, 1220-1224. https://doi.org/10.1016/j.conbuildmat.2007.01.027

Lozano, S., \& Elizabeth, E. (2018). Resistencia a compresión y flexión del adobe compactado con incorporación de bentonita sódica, utilizando suelos de diferentes canteras, Cajamarca 2016. Universidad Privada del Norte. Retrieved from https://repositorio.upn.edu.pe/handle/11537/12677

Medvey, B., \& Dobszay, G. (2020, January 30). Durability of Stabilized Earthen Constructions: A Review | SpringerLink. Geotechnical and Geological Engineering. Retrieved from https://link.springer.com/article/10.1007/s10706-020-01208-6

Mileto, C., López-Manzanares, F. V., García-Soriano, L., \& Cristini, V. (2017). Vernacular and Earthen Architecture: Conservation and Sustainability: Proceedings of SosTierra 2017 (Valencia, Spain, 14-16 September 2017). CRC Press.

Minke, G. (2005). Manual de construcción en tierra (Segunda). Editorial Fin de Siglo.

Montes Bernabe, J. L. (2011). Estudio del efecto de la fibra de bagazo Agave angustifolia Haw en la resistencia a flexión y compresión del adobe compactado. Retrieved November 11, 2020, from https://tesis.ipn.mx/handle/123456789/8292?show=full

Pekmezcí, B., Kafescíoglu, R., \& Agahzadeh, E. (2012). Improved Performance Of Earth Structures By Lime And Gypsum Addition. METU JOURNAL OF THE FACULTY OF ARCHITECTURE, 17. https://doi.org/10.4305/METU.JFA.2012.2.9

Prakaypan, W. (2002). Production of high performance building materials from flue-gas gypsum (Thesis, Chulalongkorn University). Chulalongkorn University. Retrieved from http://cuir.car.chula.ac.th/handle/123456789/25066

Rodríguez, M. A., \& Saroza, B. (2006). Determination of the optimum composition of adobe brick for a school in Cuba. Materiales de Construcción, 56(282), 53-62. https://doi.org/10.3989/mc.2006.v56.i282.27

Stulz, R., \& Mukerji, K. (1997). Materiales de construcción apropiados. IT Publications. Retrieved from http://www.fastonline.org/CD3WD_40/CD3WD/CONSTRUC/SK01AE/ES/SK01MS06.HTM

Türkmen, I., Ekinci, E., Kantarcı, F., \& Sarıcı, T. (2017). The mechanical and physical properties of unfired earth bricks stabilized with gypsum and Elazığ Ferrochrome slag. International Journal of Sustainable Built Environment, 6(2), 565-573. https://doi.org/10.1016/j.ijsbe.2017.12.003

Vilane, B. R. T. (2010). Assessment of stabilisation of adobes by confined compression tests. Biosystems Engineering, $106(4)$, 551-558. https://doi.org/10.1016/j.biosystemseng.2010.06.008

Virkkala, I., Johnson, T., Shelter, K., \& Rudanko + Kankkunen Architects. (n.d.). Building with earth-The basics. Building Trust International. Retrieved from https://www.buildingtrustinternational.org/BTIEarthToolkit.pdf

Yilmaz, I. (2004). Relationships between liquid limit, cation exchange capacity, and swelling potentials of clayey soils. Eurasian Soil Science, 37(4), 506512. 